\title{
THE USE OF GnRH ANTAGONISTS IN OVARIAN STIMULATION FOR INTRAUTERINE INSEMINATION
}

\author{
Mete ISIKOGLU \\ Gelecek the Center for Human Reproduction, Antalya, Turkey
}

\begin{abstract}
SUMMARY
The first paper entitled intrauterine insemination (IUI) was published in 1962. By time, several methods involving the technique and the ovulation induction schedules have evolved in order to improve the success rates. Although gonadotrophin releasing hormone antagonists (GnRHa) is a crucial part of assisted reproductive treatments now, concerns also arouse regarding the need for the use of it in IUI cycles. These drugs may be considered in IUI programs basically in order to prevent premature LH surges and related cycle cancellations. Although administration of a GnRH antagonist almost completely abolishes premature luteinization, it does not substantially improve the pregnancy rate. The decision of using GnRH antagonists in IUI cycles should be based primarily on the local cost/benefit analysis of individual centers. It will be prudent to limit the involvement of the antagonists in ovulation induction protocols to: patients who frequently exhibit premature LH discharges and therefore either fail to complete treatment or result in unsuccessful outcome; initiated cycles intented for IUI but converted to ART; if it is not possible for logistic reasons (weekend) to perform the insemination or for medical centers in which a gynecologist on call is not available and in order to decrease clinical task burden resulting from strict cycle monitoring such as serial transvaginal sonography and/or frequent urine tests.
\end{abstract}

Key words: GnRH antagonist, intrauterine insemination, ovulation induction

Journal of Turkish Society of Obstetrics and Gynecology, (J Turk Soc Obstet Gynecol), 2013; Vol: 10, Issue: 4, Pages: 250- 5

\section{INTRAUTERIN İNSEMINASYON İÇIN OVER STIMÜLASYONUNDA GnRH ANTAGONISTLERININ KULLANIMI}

\section{ÖZET}

Intrauterin inseminasyon (IUI) başlı̆̆ı taşıyan ilk makale 1962 yılında yayımlandı. Zaman içinde başarı hızını arttırmak amacıla teknikle veya ovülasyon indüksiyonu ile ilgili çeşitli yöntemler geliştirildi. Gonadotropin serbestleştirici hormon antagonistleri (GnRHa) yardımcı üreme tekniklerinin önemli bir parçası olmakla birlikte, IUI sikluslarında kullanımının gerekliliğine dair de merak uyandırmıştır. Bu ilaçların IUI tedavilerinde temel kullanım amacı erken LH yükselmeleri ve buna bağlı siklus iptallerinin önüne geçmektir. GnRHa uygulanması erken lutenizasyonu hemen hemen kesin olarak önlemekle birlikte, gebelik hızını belirgin şekilde arttırmamaktadır. GnRH antagonistlerinin IUI tedavilerinde kullanımı konusunda verilecek karar birincil olarak tedaviyi yürüten kliniğin yerel maliyet/yarar analizlerine dayandırılmalıdır. Buna göre IUI sırasında GnRHa kullanımı aşă̆ıdaki endikasyonlarla sınırlandırılmalıdır: sıklıkla erken LH yükselmeleri gösteren ve buna bağlı olarak da tedaviyi tamamlayamayan veya başarısız sonuç elde eden hastalar; IUI amacıyla başlatılan fakat üremeye yardımcı tedavi proğramına geçilen durumlar; inseminasyon işlemi hafta sonuna denk geldiğinde lojistik nedenlerle veya nöbetçi hekim olmaması nedeniyle işlem zamanını kaydırma gerekliliği ve ultrason takip sıklı̆̆ının ve hormon düzeyi ölçümlerinin sıklı̆̆ının azaltılması amacıyla.

Anahtar kelimeler: GnRH antagonisti, intrauterin inseminasyon, ovülasyon indüksiyonu

Türk Jinekoloji ve Obstetrik Derneği Dergisi, (J Turk Soc Obstet Gynecol), 2013; Cilt: 10, Sayl: 4, Sayfa: 250- 5

Address for Correspondence: Dr. Mete Işıkoğlu. Çağlayan mah. Bülent Ecevit Bulvarı no: 167, Lara, Antalya, Türkiye Phone: + 90 (554) 2149493

e-mail: misikoglu@hotmail.com

Received: 11 November 2011, revised: 12 November 2012, accepted: 03 March 2013, online publication: 04 March 2013 


\section{INTRODUCTION}

Gonadotropin-releasing hormone $(\mathrm{GnRH})$ antagonists have been recently introduced in clinical practice for ovarian stimulation in assisted reproduction cycles ${ }^{(1)}$. But there are scarce studies regarding the use of antagonists in intrauterine insemination (IUI) cycles so far. In women with unexplained infertility undergoing controlled ovarian hyperstimulation $(\mathrm{COH})$ with clomiphene citrate (CC) or human menopausal gonadotropin (hMG), the occurrence of a spontaneous LH surge occurs in nearly half of the total cycles(2). Sometimes LH surge occurs prematurely and represents a challenge for the practitioner. Hence, these drugs may also be considered in IUI programs in order to prevent premature LH surges.

\section{Intrauterine insemination:}

The first paper entitled intrauterine insemination (IUI) was published in $1962^{(3)}$. By time, several methods involving the technique and the ovulation induction schedules have evolved in order to improve the success rates. The technique of introducing spermatozoa into the female reproductive tract by a method other than intercourse has been used for several reasons of infertility including sexual dysfunction, unexplained infertility, hostile cervical mucus, mild male infertility and for the use of donor spermatozoa. The combination of IUI with CC or with gonadotropin stimulation provides better results than IUI alone ${ }^{(4)}$. Several methods involving the technique and the ovulation induction schedules have evolved in order to improve the success rates.

\section{The structure, effects and side effects of GnRH antagonists:}

$\mathrm{GnRH}$ is a decapeptide released at the hypothalamic level. Pulsatile GnRH stimulates the pituitary secretion of both luteinising hormone ( $\mathrm{LH}$ ) and folliclestimulating hormone (FSH) and thus controls the hormonal and reproductive function of the gonads. Its secretion is controlled by the feedback effects of gonadal steroids and peptides and a variety of neural pathways of intra- and extrahypothalamic origin. Blockade of GnRH effects may be needed to prevent premature LH surge during ovarian stimulation for IUI or assisted reproduction. GnRH agonists and antagonists are the two main groups of agents fort this purpose.
Due to the excessive selection of the follicles and the need of commencement long before stimulation precludes agonists to be a option in IUI cycles. Considering the potential flare effect of the agonists on gonadotrophin secretion, it should be continued nearly 2-3 weeks until pituitary desensitization is confirmed(5).

Multiple amino acid substitutions in the GnRH structure yield GnRH antagonists that bind to the GnRH receptor and provide competitive inhibition of the naturally occurring GnRH. GnRH antagonists can be used concomitantly with gonadotropin induction of ovulation to prevent premature LH surges. GnRH antagonists immediately and rapidly inhibit gonadotropin release by the anterior pituitary gland. Prompt suppression of pituitary gonadotropins avoids the initial stimulatory phase of the agonists. Furthermore, duration of stimulation and the amount of gonadotrophins used is lower ${ }^{(6)}$.

Discontinuation of GnRH antagonist treatment leads to a rapid and predictable recovery of the pituitarygonadal axis $(4)$.

Apart from the effects on the pituitary, agonists have been claimed to have a direct effect on ovarian steroidogenesis. Such inadvertent effects have been thought to be overcome when antagonists have been chosen.

A rapid and predictable recovery appears in pituitarygonadal axis after discontinuation of GnRH antagonists (7). The early products of antagonists either lacked potency or were associated with undesirable side effects due to histamine release. These inadvertent effects have been overcome by new generation antagonists. So far, no systemic side effects and no major local reactions have been reported following the use of thirdgeneration antagonists ${ }^{(8)}$.

\section{GnRH antagonist protocols:}

GnRH antagonists have been tested extensively in ovarian stimulation protocols for ART but there are scarce studies about the use of antagonists in IUI treatment protocols.

Currently, two treatment protocols of GnRH antagonists are used in clinical practice: the multiple-dose protocol and the single-dose protocol. Both protocols are effective and well tolerated. Single dose antagonist is administered as $3 \mathrm{mg}$ when the largest follicle reaches $14 \mathrm{~mm}$. If human chorionic gonadotrophin (HCG) is not 
administered within 96 hours of single dose injection, $0.25 \mathrm{mg} /$ day should be administered until the day of trigger hCG. Multiple dose is commenced as $0.25 \mathrm{mg}$ per day starting from the day in which a follicle $14 \mathrm{~mm}$ in mean diameter is visualized at ultrasound scan and continued until hCG administration. Multi dose protocol is preferred in IUI cycles.

$\mathrm{CC}$ pretreatment increases the sensitivity of the pituitary for $\mathrm{GnRH}$ and reduces the efficacy of subsequent GnRH antagonist in animal model. Thus, the elevated risk of premature LH surges in clinical protocols using $\mathrm{CC}$, gonadotropin and $\mathrm{GnRH}$ antagonist can be overcome by increasing the antagonist dose ${ }^{(9)}$.

The fact that GnRH antagonists cause an immediate suppression of gonadotropin concentrations while preserving pituitary responsiveness to endogenous GnRH provides flexibility in treatment ${ }^{(10)}$.

LH surges cannot be predicted precisely utilizing clinical parameters normally employed. Patients with follicles $>14 \mathrm{~mm}$ or more and with high numbers of small follicles and high oestradiol are at risk of a spontaneous LH surge (11). These variables can be used to time the administration of $\mathrm{GnRH}$ antagonist until better predictive factors are demonstrated.

\section{Premature LH surge and pregnancy rates:}

The efficacy of these agents in preventing premature LH surge has been demonstrated ${ }^{(1)}$. Several studies have also demonstrated that $\mathrm{GnRH}$ antagonists decrease the premature luteinization rates and cycle cancellation rates $(12,13)$.

A recent randomized controlled study 45 patients were undergone ovulation induction with gonadotropin while in 48 patients GnRH antagonist was added when the leading follicle was $\geq 16 \mathrm{~mm}$ and continued until the day of trigger hCG injection. Premature luteinization rates were $17,5 \%$ and $1,7 \%$ respectively. GnRH antagonist use increased the pregnancy rate significantly (clinical pregnancy rate was $22 \%$ in antagonist group and $11 \%$ in control group) ${ }^{(12)}$ while a multi-center double blind randomized controlled trial including 223 women with 552 cycles showed that adding antagonists in IUI cycles does not increase live birth rates ${ }^{(14)}$. In their randomized controlled study Steward et al enrolled 40 patients in each arm and performed ovulation induction with gonadotrophins in the first group while commenced $\mathrm{GnRH}$ antagonist $0.25 \mathrm{mg} /$ day when the leading follicle was $\geq 14 \mathrm{~mm}$ or blood E2 level was $\geq 400 \mathrm{pg} / \mathrm{mL}$. They found similar pregnancy rates $(20 \%$ and $23 \%$ respectively), while premature luteinization rate was twice as much in the control group ${ }^{(13)}$. In a review published in 2007 confining three studies and 299 cases also reported that antagonist use does not increase pregnancy rates (OR $1.595 \%$ CI 0.83- 2.8) (15). Patients with polycystic ovary syndrome have similar findings $(16)$. Authors claiming increased pregnancy rates with antagonist use in IUI cycles proposed the mechanism of higher number of mature follicles which is a result of not scaring of premature luteinization $^{(12)}$. Decreased incidence of premature luteinization may has a direct positive effect on pregnancy rates $^{(17)}$.

Analysis of seven randomized controlled studies revealed that the mean ongoing pregnancy rates increased only $5.3 \%$ by adding GnRH antagonists in IUI cycles $(95 \% \mathrm{CI}: 1.5,9.2)$ which means that antagonists should be used in 20 cycles in order to achieve one more pregnancy. Hence, use of GnRH antagonists almost definitely prevent premature luteinization while not increasing pregnancy rates significantly. Premature luteinization may be one of the results of the low quality of the growing follicle rather than the cause of it ${ }^{(18)}$.

As may be expected, use of antagonists increase the pregnancy rates in ovulation induction cycles intended to be completed with IUI and switched to ART independently from the blood estradiol level and the age of the patient(19).

In their study Martinez-Salazar and co-workers subdivided the patients with premature luteinization into two groups based on serum progesterone concentrations. They found that pregnancy rate was lower $(10.7 \%)$ in patients with premature luteinization (serum progesterone level $\geq 1.2 \mathrm{ng} / \mathrm{mL}$ or serum $\mathrm{LH} \geq 12$ IU/L or twice compared with that of day 1 ) on day of trigger hCG injection compared with that of patients without premature luteinization (29.2\%). When GnRH antagonist was used in patients who failed in their first trials, pregnancy rate was $18.1 \%(20)$.

\section{Luteal phase support:}

Luteal phase support is almost a routine part of the treatment in ART cycles and may be effective to overcome any adverse effect of the GnRH antagonists on corpus luteum. The rationale for luteal phase 
supplementation in ART derives from concerns that the act of follicular aspiration may disrupt sufficient volume of granulosa cells to impair luteal steroidogenesis ${ }^{(21)}$ and from evidence that the incidence of luteal inadequacy is increased in patients who underwent superovulation(22).

Although there exist contratictory studies(23-25), currently there is almost a consensus that luteal phase support have a positive effect on pregnancy rate (26).

Ragni and co-workers found similar clinical pregnancy rates per cycle in gonadotropin-stimulated cycles with or without GnRH antagonist therapy during IUI treatment. The same study also evaluated the luteal phase without any hormonal support, and concluded that GnRH antagonists can be safely administered in gonadotropin-stimulated IUI cycles without luteal phase supplementation because no deleterious effects of $\mathrm{GnRH}$ antagonist administration were noted on luteal progesterone concentration or on the duration of the luteal phase.

It appears that the use of a GnRH antagonist shows the same progesterone profile in the luteal phase compared with gonadotropin therapy alone in IUI ovulation induction cycles(27). A recent review concerning the luteal phase support after the use of GnRH antagonists also show that luteal phase support might not be mandatory in IUI cycles(28). GnRH antagonists may therefore be administered to these patients without luteal phase supplementation. Further studies are still needed to elucidate this issue.

\section{DISCUSSION}

The fundamental use of GnRH antagonists in the field of reproductive treatments is being an alternative to agonists in ovulation induction for ART. Although the keen competition between these two rivals has not come to an end, the past ten years passed in the favor of antagonists. Nevertheless, antagonists do not seem to replace agonists at least in the near future. The use of antagonists in treatments other than ART is still elusive.
The principal benefits to be gained from using GnRH antagonist in IUI are:

* GnRH antagonists might be useful in order to lower cancellation rates due to premature $\mathrm{LH}$ surge. In IUI cycles, GnRH agonists are not frequently used because of the excessive follicular selection they favour and because of the long pretreatment period required. GnRH agonists have the disadvantage of inducing an initial "flare effect" on gonadotropin secretion, necessitating 2-3 weeks before pituitary desensitization is achieved. GnRH antagonists, on the contrary, cause an immediate inhibition of gonadotropin secretion by competitive blocking of pituitary $\mathrm{GnRH}$ receptors so allowing a reduction both in the treatment time and in the mean number of gonadotropin ampoules administered.

* Despite contradictory reports, there are clues in favor of a positive effect on pregnancy rates.

* In ART cycles -particularly in patients diagnosed with PCOS- the antagonists appear to be associated with a lower risk of ovarian hyperstimulation syndrome (OHSS) than do agonists $(29,30)$. Using a GnRH agonist instead of hCG for triggering ovulation in antagonist used cycles will possibly reduce the risk further. Although with limited number of cases, the difference in ovarian hyperstimulation risk was not significantly higher in IUI cycles. Nevertheless, based on the knowledge gained from ART cycles, it is possible to expect statistically significant differences in further studies with extended number of cases. Hence, antagonist use may be beneficial in IUI cycles in this aspect as well.

* It is also safe with respect to the course of pregnancies and the health of offspring.

Anyway, the decision of using GnRH antagonists in OI+IUI cycles should be based on the cost/benefit analysis of individual centers. Apart from a particular subgroup of patients, routine application of antagonists will only increase the cost treatment without any effect on pregnancy rate. ESHRE Capri Workshop also stated that trying to prevent premature LH surges is not mandatory in IUI cycles ${ }^{(18)}$.

Currently it will be prudent to limit the application of antagonists with the following situations:

* patients, who frequently exhibit premature LH 
discharges and therefore fail to complete treatment;

* cycles initiated with the intention to proceed to IUI but switched to ART;

* when one or more follicles measure $\geq 14 \mathrm{~mm}$ and the probable day of insemination coincide weekend; in order to skip the weekend for logistic reasons or the lack of on call $\operatorname{staff}^{(31)}$ and

* To decrease the frequency of sonography examinations and blood hormone measurements and related clinical task burden.

\section{REFERENCES}

1. Diedrich K, Diedrich C, Santos E, Zoll C, al-Hasani S, Reissmann T, Krebs D, Klingmuller D. Suppression of the endogenous luteinizing hormone surge by the gonadotropin-releasing hormone antagonist Cetrorelix during ovarian stimulation. Hum Reprod 1994 May;9(5):788-91.

2. Costello MF, Hughes GJ, Garrett DK, Hanjani A, Steigrad SJ. A spontaneous luteinizing hormone surge is beneficial in women with unexplained infertility undergoing controlled ovarian hyperstimulation without in vitro fertilization. Int $\mathrm{J}$ Fertil Womens Med. 1998 Jan-Feb;43(1):28-33.

3. Cohen MR. İntrauterin insemination. Int J Fertil 1962 JulSep; $7: 235-40$

4. Karlstrom P-O, Bergh T, Lundkvist O. A prospective randomized trial of artificial insemination versus intercourse in cycles stimulated with human menopausal gonadotropin or clomiphene citrate. Fertil Steril 1993 Mar;59(3):554-9.

5. Nuojua-Huttunen S, Tuomivaara L, Juntunen K, Tomas C, Martikainen H. Long gonadotrophin releasing hormone agonist/human menopausal gonadotrophin protocol for ovarian stimulation in intrauterin insemination treatment. Eur J Obstet Gynecol Reprod Biol 1997 Jul;74(1):83-7.

6. Albano C, Felberbaum RE, Smitz J, Riethmuller-Winzen H, Engel J, Diedrich K, Devroey P. Ovarian stimulation with HMG: results of a prospective randomized phase III European study comparing the luteinizing hormone-releasing hormone (LHRH)-antagonist cetrorelix and the LHRH-agonist buserelin. European Cetrorelix Study Group Hum Reprod 2000 Mar; 15(3):526-31

7. Moghissi KS. A clinician's guide to the use of gonadotropinreleasing hormone analogues in women. Medscape Womens Health. 2000 Jan;5(1):5

8. Tarlatzis BC, Bili H. Safety of GnRH agonists and antagonists Expert Opin Drug Saf. 2004 Jan;3(1):39-46.

9. Engel JB, Felberbaum RE, Eilers W, Polack S, Ortmann O,
Diedrich K. Clomiphene-induced LH surges and cetrorelix. Reprod Biomed Online. 2002 Sep-Oct;5(2):109-11.

10. Felberbaum RE, Diedrich K. Gonadotropin- releasing hormone antagonists: will they replace the agonists? Reprod Biomed Online. 2003 Jan-Feb;6(1):43-53.

11. Cunha-Filho JS, Kadoch J, Righini C, Fanchin R, Frydman R, Olivennes F. Premature LH and progesteron rise in intrauterin insemination cycles: analysis of related factors. Reprod Biomed Online 2003 Sep;7(2):194-9.

12. Bakas P, Konidaris S, Liapis A, Gregoriou O, Tzanakaki D, Creatsas G. Role of gonadotropin-releasing hormone antagonist in the management of subfertile couples with intrauterin insemination and controlled ovarian stimulation. Fertil Steril 2011 May;95(6):2024-8. Epub 2011 Feb 19.

13. Steward RG, Gill I, Williams DB, Witz CA, Griffith J, Haddad GF. Cetrorelix lowers premature luteinization rate in gonadotropin ovulation induction-intrauterin insemination cycles: a randomized-controlled clinical trial. Fertil Steril 2011 Jan;95(1):434-6.

14. Cantineau AE, Cohlen BJ, Klip H, Heineman MJ; Dutch IUI Study Group Collaborators. The addition of GnRH antagonists in intrauterin insemination cycles with mild ovarian hyperstimulation does not increase live birth rates-a randomized, double-blinded, placebo-controlled trial. Hum Reprod. 2011 May;26(5):1104-11. Epub 2011 Feb 20.

15. Cantineau AECantineau AE, Cohlen BJ, Heineman MJ. Ovarian stimulation protocols (anti-oestrogens, gonadotrophins with and without GnRH agonists/antagonists) for intrauterine insemination (IUI) in women with subfertility. Cochrane Database Syst Rev. 2007 Apr 18; (2): CD005356.

16. Stadtmauer LA, Sarhan A, Duran EH, Beydoun H, Bocca S, Pultz B, Oehninger S. The impact of a gonadotropin-releasing hormone antagonist on gonadotropin ovulation induction cycles in women with polycystic ovary syndrome: a prospective randomized study. Fertil Steril 2011 Jan;95(1):216-20. Epub 2010 Jul 1.

17. Allegra A, Marino A, Coffaro F, Scaglione P, Sammartano F, Rizza G, et al. GnRH antagonist induced inhibition of the premature LH surge increases pregnancy rates in IUI stimulated cycles. A prospective randomized trial. Hum Reprod. 2007 Jan;22(1):101-8.

18. ESHRE Capri Workshop Group. Hum Reprod Update 2009; May-Jun;15(3):265-77. Epub 2009 Feb 23.

19. Quaas AM, Missmer SA, Ginsburg ES. Gonadotropin-releasing hormone antagonist use is associated with increased pregnancy rates in ovulation induction-intrauterin insemination to in vitro fertilization conversions, independent of age and estradiol level on the day of human chorionic gonadotropin administration. 
Fertil Steril 2010 Feb;93(2):605-8. Epub 2009 Mar 26.

20. Martinez-Salazar J, Cerrillo M, Quea G, Pacheco A, GarciaVelasco JA. GnRH antagonist ganirelix prevents premature luteinization in IUI cycles: rationale for its use. Reprod Biomed Online 2009 Aug;19(2):156-61.

21. Kreitmann O, Nixon WE, Hodgen GD. Induced corpus luteum dysfunction after aspiration of the preovulatory follicle in monkeys. Fertil Steril 1981 Jun;35(6):671-5.

22. Kubik CJ. Luteal phase dysfunction following ovulation induction. Semin Reprod Endocrinol 1986; 4: 293- 303.

23. Daya S. Efficacy of progesteron support in the luteal phase following in-vitro fertilization and embryo transfer: metaanalysis of clinical trials. Hum Reprod 1988 Aug;3(6):731-4.

24. Belaisch-Allart J, De Mouzon J, Lapousterle C, Mayer M. The effect of HCG supplementation after combined GnRH agonist/HMG treatment in an IVF programme. Hum Reprod 1990 Feb;5(2):163-6.

25. Kupferminc MJ, Lessing JB, Amit A, Yovel I, David MP, Peyser MR. A prospective randomized trial of human chorionic gonadotrophin or dydrogesterone support following in-vitro fertilization and embryo transfer. Hum Reprod 1990 Apr;5(3): $271-3$.

26. Soliman S, Daya S, Collins J, Hughes EG. The role of luteal phase support in infertility treatment: a meta-analysis of randomized trials. Fertil Steril 1994 Jun;61(6):1068-76.

27. Ragni G, Vegetti W, Baroni E, Colombo M, Arnoldi M, Lombroso G, Crosignani PG. Comparison of luteal phase profile in gonadotropin stimulated cycles with or without a gonadotropin-releasing hormone antagonist. Hum Reprod 2001 Nov;16(11):2258-62.

28. Tarlatzis BC, Bili HN. Gonadotropin-releasing hormone antagonists: impact of IVF practice and potential non-assisted reproductive technology applications. Curr Opin Obstet Gynecol 2003 Jun;15(3):259-64.

29. Howles CM. The place of gonadotrophin-releasing hormone antagonists in reproductive medicine. Reprod Biomed Online 2002;4 Suppl 3:64-71.

30. Kol S, Homburg R, Alsbjerg B, Humaidan P. The gonadotropinreleasing hormone antagonist protocol--the protocol of choice for the polycystic ovary syndrome patient undergoing controlled ovarian stimulation. Acta Obstet Gynecol Scand. 2012 Jun; 91(6):643-7. doi: 10.1111/j.1600-0412.2012.01399.x. Epub 2012 Apr 30.

31. Matorras R, Ramón O, Expósito A, Corcóstegui B, Ocerin I, Gonzalez-Lopera S, Rodríguez-Escudero FJ. Gn-RH antagonists in intrauterin insemination: the weekend-free protocol. J Assist Reprod Genet 2006 Feb;23(2):51-4. Epub 2006 Mar 22. 